\title{
On the Driving Force of the New Types of Hainan Cruise Tourism - Based on Comparative Study of the Domestic Development
}

\author{
Jue WANG $^{1}$ and Yu-xiu ZHANG ${ }^{2}$ \\ ${ }^{1}$ Hainan TV\& Radio University, Haikou, Hainan, China, 570208 \\ ${ }^{2}$ Hainan TV\& Radio University, Haikou, Hainan, China, 570208
}

Keywords: Cruise tourism, New types, Driving force, The background of one belt and one road strategy.

\begin{abstract}
Hainan promotes the new types of cruise tourism. The article focuses on the driving force of the new types. In order to further our analysis on driving forces of new types of cruise tourism and thus promote the development of new types of cruise tourism in Hainan, we carried out the comparison between Hainan and other domestic regions, furthermore, we conclude that there are common characters among these regions and Hainan has unique quality of driving forces of new types of cruise tourism. Hainan can develop new types of cruise tourism with its unique feature.
\end{abstract}

\section{Introduction}

Under the background of the Belt and Road Initiative, in order to promote the construction of the China-ASEAN Ocean Tourism Economic Circle, Hainan will boost the development of cruise industry as the core of marine tourism (Hainan Provincial Tourism Development Commission, 2015). Driving force for new types of cruise tourism in Hainan becomes increasingly stronger. Gao Limin, Cheng Wei and Shi Yanjun (2012) pointed out that in tourism, new type means a novel product which is developed to fulfil psychological, emotional and aesthetic enjoyment of tourists, and its creation, development and maturity is a result of social development, driven by the impetus of both internal and external forces. Internal forces refer to a series of changes developed inside the cruise industry that promote initiatives to guide and pioneer the needs of tourism consumers; while the external forces indicate those factors outside the industry to adapt new needs of tourists, including demand changes, competitions, new market opportunities, etc..

While both internal and external forces are key factors for the development of new types of cruise tourism, safeguards from policy, institution and funding, etc., are also indispensable.

\section{Comparison of Driving Forces of New Types of Cruise Tourism between Hainan and Other Domestic Home Port Regions}

In order to further our analysis on driving forces of new types of cruise tourism and thus promote the development of new types of cruise tourism in Hainan, a comparison is carried out to outline the common characters among regions and unique quality of Hainan. (Table 1: Cruise Tourism Development of Home Port Regions (partly)) 
Table 1. Cruise Tourism Development of Home Port Regions (partly)

\begin{tabular}{|c|c|c|}
\hline Region & $\begin{array}{c}\text { Previously developed cruise } \\
\text { tourism products }\end{array}$ & $\begin{array}{l}\text { New types of cruise tourism in } \\
\text { the last } 2 \text { years (or planning) }\end{array}$ \\
\hline $\begin{array}{l}\text { Zhoushan, } \\
\text { Zhejiang }\end{array}$ & / & $\begin{array}{l}\text { 1. Zhoushan to Taiwan, Japan and Japan by the } \\
\text { way of Keelung, Taichung, Kaohsiung and } \\
\text { Hualien Port of Taiwan; } 2 \text {. Keelung, Taiwan to } \\
\text { Zhoushan; } 3 \text {. To Vietnam }\end{array}$ \\
\hline $\begin{array}{l}\text { Coastline of } \\
\text { Guangxi }\end{array}$ & Beihai to Vietnam & $\begin{array}{l}\text { 1. Guangxi Beibu Gulf to ASEAN;2. New } \\
\text { tourism type of "express railway+ cruise"; } 3 \text {. } \\
\text { Beihai to main Coastal cities of ASEAN }\end{array}$ \\
\hline $\begin{array}{l}\text { Tsingtao, } \\
\text { Shandong }\end{array}$ & Tsingtao to Korea and Japan & $\begin{array}{l}\text { 1. Tsingtao to Okinawa, Japan; 2. Plan to } \\
\text { Rashid, Dubai;3.To Vietnam }\end{array}$ \\
\hline Shanghai & Shanghai to Korea and Japan & $\begin{array}{l}\text { 1. To the Middle East; 2. To Japan and Korea; } \\
\text { 3. Cruise global travel; } 4 \text {. To Vietnam }\end{array}$ \\
\hline Tianjin & Tianjin to Korea and Japan & $\begin{array}{l}\text { 1. To Busan, Cheju and Seoul; 2. To Taiwan } \\
\text { and cooperating with Royal Caribbean Cruise; } \\
\text { 3. To Vietnam }\end{array}$ \\
\hline $\begin{array}{l}\text { Haikou, Sanya, } \\
\text { Hainan }\end{array}$ & $\begin{array}{l}\text { To Korea, Japan, Thailand } \\
\text { and Singapore }\end{array}$ & $\begin{array}{l}\text { 1. Sanya to Hong Kong; 2.Sansha Cruise } \\
\text { Tourism; } 3 \text {. To Vietnam }\end{array}$ \\
\hline $\begin{array}{l}\text { Xiamen, } \\
\text { Fujian }\end{array}$ & $\begin{array}{l}\text { To Vietnam, Hong Kong and } \\
\text { the Xisha Islands }\end{array}$ & $\begin{array}{l}\text { 1. One-hundred thousand tourists in } \\
\text { international cruise tour across the Taiwan } \\
\text { Strait and maiden voyage from Xiamen Home } \\
\text { Port of Superstar Gemini; } 2 \text {."Express railway } \\
\text { + cruise" model; 3. To main cities in Maritime } \\
\text { Silk Road; 4. To Vietnam; 5. Forty-day } \\
\text { Charter cruise agreement between Xiamen } \\
\text { cruise home port and Royal Caribbean }\end{array}$ \\
\hline
\end{tabular}

(Data source: from research materials and Internet, updated by May 2015)

\section{Common characters of driving forces of new types of cruise tourism among regions}

From external driving forces perspective. (1) Under the background of Belt and Road Initiative, new types of business boom after the integration of hinterland tourism resources. While products of new maritime tourism take the lead, cruise tourism become the core and focus of this trend. (2) These regions possess geographic advantage along the maritime Silk Road. Not only previously developed cruise tourism products but new types of cruise tourism in the last 2 years (or planning), rely heavily upon their locations. (3) Based on geographic location, destinations of previously developed cruise lines are countries and regions of Northeast Asia, Southeast Asia. Meanwhile, these regions develop local home ports as ports of embarkation and create new types of cruise tourism, for example, Guangxi will launch cruise lines from Beihai to ASEAN countries, and Xiamen opens cruise lines to Taiwan. (4) Comparing previously developed cruise tourism products, new cruise lines developed in the last 2 years diversify and present a trend to extend ports of call throughout the maritime Silk Road. (5) Because demands of domestic and overseas tourists diversify and upgrade, sightseeing tour becomes inadequate to adapt the changes. As a result, developing appropriate cruise products to meet customer needs emerges as one of the driving forces of new type of cruise tourism. (6) The existence of "common characters" of external driving forces leads to homogeneity development. Not only Xiamen, Beihai, Shanghai and Tianjin have all opened cruise lines to Vietnam, but Bohai Ferry plans to launch direct line to Vietnam. In consequence, "Hainan-Vietnam" cruise tourism would face more severe competition from other regions in the country. 
From internal driving forces perspective. Under the framework of Belt and Road Initiative, internal driving forces of Hainan tend to be similar with other regions: integrative development of cruise tourism with other industries, extension of cruise tourism chain, needs for further optimizing structure of cruise tourism products and strong increase in cruise tourism, etc.

From perspective of safeguard. There are similarities between Hainan and other domestic regions, whether concerning institution, policy or funding, for example, both central and local government carry out supportive policies to facilitate cruise industry in order to promote the construction of China-ASEAN maritime tourism circle. According to Overall Planning on Cruise Tourism Development in China to be introduced in October 2015, the basic pattern of cruise home ports will be "one line and three points", which mean cruise lines development will focus on Southeast Asia and cross-Strait, and three cores are represented by Sanya and Xiamen (South), Tianjin (North), and Shanghai (Central). In Guiding Opinions of the Ministry of Transport on Promoting the Sustainable and Healthy Development of Cruise Industry in China introduced in 2014, Tianjin, Shanghai, Fujian and Hainan were designated as pilot provinces of Cruise transportation. In 2015, Planning Scheme of National Coastal Cruise Ports listed Sanya as one among eight national priority cruise home ports.

Furthermore, development of domestic cruise industry starts its transformation from government-leaded to a government-market mechanism. For instance, closely following Belt and Road Initiative, Hainan provincial government cooperates with HNA Tourism Group to construct tourism financial institution, and establish tourist industry funds and cruise funds. Implementation Opinions on Accelerating the Construction of Shanghai International Shipping Centers fostered cruise economy, supported to establish cruise development funds and encouraged to create joint-ventured cruise companies to develop cruise business. In Chinese stock markets, there are many listed companies related to cruise industry. A large number of cruise industry companies go public indicates that cruise tourism industry in China could enjoy diverse financing and competition institutions with multi-channel, multi-agent, multi-model.

\section{Unique Quality of Cruise Tourism Driving Forces of Hainan}

From External Driving Forces Perspective. Differences on tourism resource superiority distinguish Hainan from other regions concerning cruise tourism integration and penetration. In order to attract cruise tourists to disembark, other regions integrate maritime tourism with hinterland cultural tourism, some more traditional, others more creative with modern features. For example, surrounding two themes, "Sea" and "Buddhism", Zhejiang focuses on developing maritime tourism products represented by "Eight Marvelous Tours" of Zhoushan Islands. By utilizing marine resource advantage, Zhejiang builds cultural theme islands and creates several integrated festivals with international elements and distinct maritime cultural characteristics, including China Maritime Cultural Festival, China International Sand Sculpture Festival, China Putuo Mountain South Sea Guanyin Cultural Festival, etc.

Hainan strives to integrate new types of cruise tourism with its rich hinterland tourism resources. In 2003, provincial tourism authority launched a poll for top 10 favorite tourist attractions. The poll showed that "coconut wind and ocean charm" were the most attractive characters in Hainan. Surveys in recent years reveal that "unique and abundant biological resources, superior environment" are the most important features of Hainan. As a result, Hainan has developed an integrated business of "cruise tourism 
plus biological tourism". In summary, cruise tourism in Hainan has established a "blue \& green" model which blue sky and sea complement green land each other.

Moreover, due to difference in location, competitive edge and development orientation, new types of cruise tourism in Hainan show unique characters. For instance, there will be four types and a dozen new cruise lines in Hainan, which "Sansha(South China Sea) routes" will be the most significant. According to the plan, Sanya could open a loop cruise line "Phoenix International cruise port--Yongxing Island--Phoenix International cruise port" in the near future. Tourists would be able to enjoy the beauty of the South China Sea by cruising a bigger circle, "Phoenix International cruise port--Yongxing Island--Dong Island--Zhongsha Islands--Nansha Islands--Phoenix International cruise port" in the long term. As Chou Lingqiang (2012), Dean of Tourism College, Zhejiang University pointed out, "Sansha Cruise tourism is of significant importance among entire development of maritime tourism, especially from the sense of strategy."

From internal driving forces perspective. Development of cruise tourism in Hainan is lagged behind other regions, and its unbalanced structure is needed to be optimized. Cruise lines embarking from Hainan home ports are less attractive and competitive than others lines as a whole. Presently, most of the cruise lines launched from Hainan are short-range routes, including Vietnam (Danang, Halong Bay and Hue, etc.,), Hong Kong, Xisha Islands. Comparing to other mid-range and long-range lines in China, which depart for Southeast Asia, Northeast Asia, or even around the globe, the destinations of cruise lines from Hainan are less attractive. The prospects of these cruise lines are unclear.

From Safeguard Perspective. Hainan enjoys unique policy superiority since the construction of international tourist island became a national strategy. As for institutional safeguard, Hainan is building its upgraded version of international tourist island: a special zone of tourism in China, emphasizing on developing core tourism products with Hainan characters (Lu Zhiyuan, 2015), among which are maritime tourism products; a series of direct or indirect supportive policies, such as, " 26 visa-free countries" policy, "offshore visa-free" policy, cruise tourism offsite certificate policy, offshore duty-free policy, etc. These policies give Hainan a hard-won advantage.

In summary, differentiation inside the industry and integration with other industries become more intense, transforming from single industrial structure to composite industrial structure; change from seller's market to buyer's market means more competition and tourists' demand become more diverse; along with the launch of Year of China-ASEAN Maritime Cooperation, maritime tourism will shift from isolation to win-win cooperation. All the above are driving elements of new types of cruise tourism in Hainan.

\section{Developing New Types of Cruise Tourism with Hainan Feature}

According to the differences of driving forces between regions and unique characters of Hainan, new types of business with Hainan features should be developed to avoid vicious competition by homogenization, and establish cooperation platform on win-win basis with other regions.

In 2015, striving to become a distribution center, Hainan not only introduces tour routes themed "South China Sea Silk road", but also encourages Chinese tourists visiting countries and regions along the maritime Silk Road departing from Hainan(Going-out), and attracts foreign travelers taking vacations in Hainan or visiting 
other provinces via Hainan(Bringing-in). These approaches all contribute the formulation of new types of business.

\section{New Types of Cruise Tourism with Hainan Features Will Bring in Tourists}

When ports in Hainan become ports of call to accommodate visitors, development of new format of cruise tourism should integrate with hinterland tourism to attract visitors to disembark.

From External Driving Forces Perspective. New types of cruise tourism in Hainan could integrate with its advantage on location and development orientation. Hainan could utilize its strategic position in South China Sea and advantage on location to create Sansha (South China Sea) cruise tourism products; Relying on geographic closeness and cultural likeness between Hainan and countries around South China Sea, Hainan could build round-South China Sea cruise tourism circle together with these countries, laying foundation for the progress of construction of China-ASEAN maritime tourism economic circle.

Hainan is becoming one of the most famous wedding ceremony destinations nationally, even globally, and its international wedding festival is an influential brand. By developing competitive products like "cruise plus wedding tourism," Hainan can upgrade and optimize tourism products. Moreover, Hainan is building an upgraded version of International Tourist Island: world first-class tourism zone and pioneer of " 21 century maritime Silk Road" construction. Positioning itself as paradise of "leisure, dwelling, shopping, food, medical treatment, healthcare, entertainment, and distinctive culture," Hainan devotes its efforts to build an "eco fortune land" with best environment, where visitors can indulge in a world of coconut wind and blue sea. Focusing on ecology, health and leisure, Hainan could exploit its edge on natural resources by developing a new business type as "cruise + ecology + health + leisure + folklore" or even "cruise + round island tour".

From Internal Driving Forces Perspective. Cruise tourism can integrate with other tourism industries. From internal driving forces perspective, cruise tourism can integrate with other tourism industries, for example, "cruise plus forest exploration", "cruise plus countryside", "cruise plus ecology tourism like body shaping, healthcare, or fresh air." Moreover, Hainan could build a route themed "cruise plus South China Sea Silk Road" by integrating seven South China Sea Silk Road traveling lines since 2015 with cruise tourism.

From Safeguard Perspective. New types of cruise tourism in Hainan can utilize its unique policy edge. From safeguard perspective, duty-free tourism becomes more attractive due to unique offshore duty-free policy in Hainan. Thus, "cruise plus duty-free tourism" could attract cruise travelers to disembark and enjoy special competitive advantage; Outline of Hainan international tourism island construction and development program suggests that golf sports should be integrated with sightseeing, leisure \& vacation, medical treatment \& healthcare and extend the chain of golf industry. During winter, a large number of golfers visit Hainan, not only from overseas, such as Japan, Korea, but from domestic regions. Hence, Hainan could exploit more tourist market by developing new business type such as "cruise plus golf".

\section{New Types of Cruise Tourism in Hainan Encourage Chinese Tourists Going Out}

When ports in Hainan become home ports and output center of travelers, special designed cruise line should be launched to encourage tourists going out. 
From External Driving Forces Perspective. New types of cruise tourism in Hainan can integrate with its advantage on geographic location. Being the "bridgehead" between China and ASEAN countries due to its geographic location, Hainan is building Round-South China Sea cruise tourism circle with ASEAN countries, which creates adequate basis for constructing tourism cooperation platform. In order to formulate cruise tourism circle with culture integration, Hainan needs to design cruise lines between Hainan and ASEAN with cruise ships embark from home ports of each side, destinations including main cities alongside "Maritime Silk Road", especially "South China Sea Silk Road".

From Internal Driving Forces Perspective. New types of cruise tourism in Hainan can integrate with other industries on the industrial chain. From second half of 2015, Hainan will launch a one-trip, multi-stop "round-South China Sea" transnational cruise loop line. Several cruise companies, including Loyal Caribbean, will join business operation and construction of the line. Cruise ship will call at Vietnam, the Philippines, Taiwan, Hong Kong, and Hainan, truly implementing the concept of "one-trip, multi-stop." Furthermore, in order to absorb cruise companies worldwide to open new lines between Hainan to ASEAN, joining together with Hong Kong, Taiwan and the Philippines, Hainan will build "Asian cruise line case" platform. Hainan could also develop other international lines by cooperating with HNA Tourism Group or other international cruise giants.

From Safeguard Perspective. New types of cruise tourism can take advantage of supportive policies. Unique policy superiority such as "visa-free, duty-free and opening air traffic rights" is the essence of international tourism island. Since 2010, Hainan has carried out visa-free policy to 26 countries. Besides its unique policy superiority, Hainan should take full advantage of other national policies. In 2015, as Japan and Korea implement visa-free policy to cruise visitors, cruise tourism in China enters "visa-free era". As Deng Xiaogang, then deputy general director of Hainan Provincial Tourism Development Commission suggested in 2011, based on two home ports, Haikou and Sanya, cruise industry of Hainan should not only open around-Hainan Island cruise lines, but exploit more routes to Macau, Hong Kong, Taiwan, and countries nearby. By utilizing visa-free policies and strengthening cooperation within Pan-Pearl River region, Hainan could build a 21 century human and cultural exchange platform of modern maritime Silk Road, and develop cruise lines to "10 ASEAN countries plus Japan and Korea" and Pan-Pearl River region, i.e., embarking from Sanya/Haikou, via XiamenlShanghailZhoushan, to several ports of call of Singapore, Malaysia, Thailand, Macau, Hong Kong, Taiwan, and reaching Japan or Korea as destination. Besides, as Japan and Korea are target markets for golf tourism of Hainan, it is highly recommended that direct cruise lines should be opened between Hainan and Japan\Korea.

\section{Conclusions}

As mentioned above, new types of cruise tourism in Hainan are driven by both internal and external forces, escorted by essential safeguards; comparing with other regions in the country, there are common characters of cruise tourism driving forces, as well as unique feature of Hainan, all of which make contribution to the birth of new types of cruise tourism in Hainan. Hainan should make use of the unique feature to form its competitive advantages. 


\section{Acknowledgement}

This research was financially supported by 2014 Philosophical and Social Sciences Project in Hainan Province "Comparative Research on Competitiveness of Hainan Cruise Tourism at Home and Abroad" (number: HNSK14-21)

\section{References}

[1] Li-min Gao, Wei Cheng and Yan-jun Shi: submitted to Journal of 2012 Annual Conference of Chinese Tourism Science (2012). "In Chinese".

[2] Information on

http://zjrb.zjol.com.cn/html/2014-08/28/content_2800812.htm?div=-1 .

[3] Information on http://www.erazj.com. 